\title{
US biologists decry funding changes
}

\section{National Science Foundation policy may harm tenure seekers.}

\section{BY HELEN SHEN}

“T This is the farthest I think that I've stuck my neck out," says Sarah Hobbie, an ecologist at the University of Minnesota in Saint Paul. Policy changes at the US National Science Foundation (NSF) are giving life scientists in some fields fewer opportunities to apply for funding, so Hobbie is now at the forefront of a campaign to persuade the NSF to rethink its approach.

In August, Hobbie garnered more than 550 signatures with an open letter to the NSF that says the changes, put in place last year, are jeopardizing the careers of young scientists. She has also surveyed the ecology community, which relies heavily on NSF funding, about what it thought was the best way forward for the agency. Of the 1,622 responses she received, only $13 \%$ favoured the NSF's changes over an alternative devised by Hobbie and her colleagues.

At the heart of the dispute are changes to the NSF's application process for grants in organismal and environmental biology. The two divisions account for about half of the US\$700 million that the agency will spend on the life sciences in 2012. In the past, researchers had two chances to apply for funding each year. Now they have just one opportunity, in two stages. For the first stage, researchers submit a short 'pre-proposal' in January, which is then screened by reviewers. Researchers who clear this hur-

dle are invited to submit full proposals by 2 August. Grant winners are awarded funding the following year.

The NSF says

"With a single
decision, you've
made an abrupt
change that will
affect a lot of
people."

that it expects to award roughly the same number of grants as in previous years, but the revised process will reduce the burden on grant reviewers. "The old system had reached breaking point," says John Wingfield, who heads the biology directorate at the NSF in Arlington, Virginia. He adds that the change has "created some interest in other directorates".

Hobbie, whose two pre-proposals were turned down this year, must now wait until January to try again for the chance to submit a full proposal in August. If approved, that project would probably not receive funding until 2014. She says that such long gaps between resubmissions have a domino effect because the delays to research and publications can be career-limiting for younger researchers striving to establish themselves and earn tenure.

"Instead of 10 or 12 opportunities to put in a proposal before tenure, it's 5 or 6 now," says Jim Heffernan, an ecologist in his first year of an assistant professorship at Duke University in Durham, North Carolina.

Another change, which prohibits researchers from acting as principal investigators on more than two proposals a year, is equally unpopular. "Strategically, I need to be the lead principal investigator on whatever grant I get," says Stan Harpole, an ecologist and assistant professor at Iowa State University in Ames, who is two years from his tenure evaluation.

\section{COMMON CONCERN}

Simmering criticisms of the new policies bubbled over in August at a panel discussion during the annual meeting of the Ecological Society of America in Portland, Oregon. It was there, Hobbie says, that she realized that her colleagues shared her concerns. The open letter she sent later that month led to a private meeting with Wingfield on 10 September. A week later, the heads of 33 life-sciences departments and programme leaders from several US universities sent a letter to the NSF expressing similar worries.

"With a single decision at the NSF, you've made an abrupt change that will affect a lot of people," says Kenneth Petren, head of biological sciences at the University of Cincinnati in Ohio, who signed the second letter. "I'm most concerned younger people will decide there's a better career path for them."

On 3 October, Wingfield told Nature that he understands the concerns, but that the NSF has opted not to reverse its policy for now. Instead, he says, the agency will evaluate the changes over the next few grant cycles. Hobbie and Petren say that such monitoring should involve dialogue with affected researchers.

"Engaging with the community is the only way they're going to assess certain types of impacts on science," says Hobbie. "I'm quite disappointed that I haven't heard anything in that direction." - 